\title{
DO RENASCENTISTA AO CONTEMPORÂNEO: ROMEO AND JULIET E SUA ADAPTAÇÃO AO QUADRADO
}

\author{
From the renascence to the comtemporary: Romeo and Juliet and its squared \\ version
}

\author{
Paulo Henrique ESPURI, UENP ${ }^{1}$ \\ Eliane Segati RIOS-REGISTRO, UENP ${ }^{2}$
}

RESUMO: Segundo as Diretrizes Curriculares da Educação Básica do Paraná (Paraná, 2008, p.26), os sujeitos são frutos de seu período sócio histórico. Por isso, compreendemos que o processo de ensino deve estar em consonância com as modificações sociais pelas quais passamos. Tal concepção implica repensar sobre os instrumentos de ensino, bem como a perspectiva sob a qual práticas de ensino e aprendizagem se efetivam. Somado ao exposto, há também e a necessidade de se desenvolver atividades sob uma perspectiva multisemiótica, contextualizada, que contemple gêneros textuais e artefatos tecnológicos para o ensino. Em face de tal cenário, utilizamos uma webquest para a criação de uma sequência didática, com o objetivo de promover o desenvolvimento das capacidades de linguagem dos alunos (DOLZ \& SCHNEUWLY, 2004) e de contemplar as especificidades dos diferentes contextos de produção de Romeo and Juliet, de William Shakespeare, e sua versão adaptada para HQ, por Maurício de Souza e Yara Maura Silva. O presente trabalho objetiva analisar comparativamente a versão original de Romeu e Julieta e uma adaptação brasileira em HQ e descrever atividades da sequência didática subsidiadas por tal análise (BRONCKART, 2009). Concluímos que a presente proposta pode promover práticas de ensino e aprendizagem significativas.

PALAVRAS-CHAVE: Sequência didática; HQ; Interacionismo Sociodiscursivo

ABSTRACT: According to the Paraná State Curriculum Guidelines for Basic Education, individuals are influenced by their sociohistorical period. Hence, we understand that the teaching process must be according to the social changes we go through. This conception involves the rethinking about the teaching tools, as well as the perspective under which teaching and learning practices happen. In addition to that, there is also the need to develop activities under a multisemiotic and contextualized perspective that comprises text genres and technological artifacts for teaching. In the light of this, we used a Webquest to develop a didactic sequence, aiming to promote the development of the students' language capacities (DOLZ; SCHNEUWLY, 2004) as well as to take into account the specificities of different contexts of production of Romeo and Juliet by Shakespeare and its comics version by Mauricio de Souza and Yara Maura Silva. This

\footnotetext{
${ }^{1}$ Mestrando no programa de Estudos da Linguagem (UEL) E graduado em Letras Anglo-Portuguesas pela Universidade Estadual do Norte do Paraná. phespuri@ hotmail.com.

${ }^{2}$ Doutora em Estudos da Linguagem (UEL) e professora adjunta na UENP. eliane_segati@uenp.edu.br.
} 
work aims at analyzing comparatively the original version of Romeo and Juliet, by Shakespeare and its Brazilian adaptation to comics, as well as describing activities from

the didactic sequence created from such analysis (BRONCKART, 2009). We can conclude that this research may be able to promote meaningful teaching and learning practices.

KEYWORDS: Didactic sequence; Comics; Sociodiscursive Interactionism

\section{INTRODUÇÃ̃}

Conforme as Diretrizes Curriculares da Educação Básica (PARANÁ, 2008) (doravante DCE), o papel da escola é o de formar cidadãos críticos e reflexivos. Tal afirmação implica, também, a de refletir sobre a maneira pela qual o ensino de língua inglesa e literatura em língua inglesa tem se efetivado, principalmente em relação a gêneros literários, uma vez que, análises de livros didáticos (RIOS-REGISTRO, 2014) demonstram que, apesar da existência de alguns gêneros da esfera da criação literária, faltam, ainda, atividades que façam o aluno refletir sobre os elementos literários que o constituem com tal, contribuindo para a compreensão de sua literariedade e a representação dessa no percurso da humanidade.

Ademais, é fato que as sociedades se reconfiguram e, consequentemente, os indivíduos que nelas estão inseridos (BRONCKART, 2009). Assim sendo, podemos afirmar que o perfil discente presente em nossas escolas públicas hoje é diferente daquele encontrado há uma década, por exemplo. Por fazemos parte de uma realidade globalizada, repleta de textos multimodais e tecnologias digitais, acreditamos que tal realidade deva estar presente na escola, considerando o seu objetivo enquanto formadora de cidadãos. Conforme Bakhtin (1997), os gêneros estão presentes em todas as esferas sociais e, por estarem intrinsecamente ligados a elas, assumem um caráter flexível frente às transformações pelas quais passamos. Com efeito, encontramos nos gêneros textuais ferramentas para tornar o ensino de língua inglesa e de literatura em língua inglesa mais significativo, haja vista que se adaptam a novas realidades (BRONCKART, 2003).

Dessa maneira, desenvolvemos uma sequência didática (DOLZ E SCHNEUWLY, 2004) com dois objetivos. O primeiro é o de aproximar um cânone literário a uma produção contemporânea contemplando os aspectos ideológicos dos diferentes contextos de produção de Romeo and Juliet, de Shakespeare, e sua versão adaptada para HQ, por Maurício de Souza e Yara Maura Silva. Por exemplo, por que Juliet toma um veneno para 
solucionar um conflito ao passo que Mônica enfrenta todos com seu coelhinho? Quais valores renascentistas podem estar vinculados ao veneno tomado por Juliet? E quais os possíveis valores relacionados à postura e atitudes de Mônica? O segundo objetivo, tão importante quanto o primeiro, é o de viabilizar a apreensão de alguns elementos constitutivos do gênero HQ.

Bagno (2005), em seus estudos sobre educação linguística, aponta a importância de um trabalho com obras literárias que não se deixe enrijecer pela perspectiva de teorização de cânones excessivamente esquemática. Assim, o autor advoga a necessidade se se lançar olhares sobre a formação mais crítica e reflexiva do leitor. Como resultado de tais reflexões, optamos por articular o estudo de Romeo and Juliet, um cânone, a sua adaptação contemporânea em quadrinhos. Assumimos perspectivas voltadas aos gêneros textuais enquanto megainstrumentos de ensino de modo a contemplarmos em nossa sequência didática (DOLZ, NOVERRAZ E SCHNEUWLY, 2004) elementos multimodais e valores presentes nos contextos de produção dos textos selecionados que intencionam a promoção de um ensino de literatura de língua inglesa desarticulado das referidas perspectivas cristalizadas na formação de leitores.

Considerando o exposto, esse artigo visa apresentar como as atividades desenvolvidas sob a perspectiva adotada podem ir ao encontro das DCE. Para tal, apresentaremos inicialmente o alicerce teórico sobre os quais construímos nossas atividades. Em seguida, discorreremos sobre as lentes que viabilizaram a análise de dados advindos de nossa SD. Finalmente, iremos expor a supracitada análise, bem como nossas considerações finais sobre a presente pesquisa.

\section{O PERCURSO TEÓRICO}

Conforme as DCE (PARANÁ, 2008), os sujeitos são influenciados pelo seu período sócio histórico e devem, portanto, ter acesso a uma escola que contemple para dentro de seus muros a sociedade em que se insere. Além disso, o referido documento defende que os conteúdos presentes no processo de ensino devem ser tratados de maneira contextualizada, o que implica refletir sobre o modo pelo qual o ensino de LI tem se dado na educação básica.

Sendo assim, uma vez compreendidas tais preconizações, não é difícil concluir que as abordagens presentes em nosso sistema de ensino devem ser adaptadas de modo a 
preparar nossos alunos para compreender nossa realidade globalizada e ideologicamente heterogênea. Não obstante, com base em nossas análises de livros didáticos (RiosRegistro, 2014), podemos considerar que as atividades relacionadas ao ensino de LI e de literatura de língua inglesa possuem um único eixo: o gramatical.

Sabemos que apoiar atividades para o ensino de línguas e literaturas unicamente na gramática não torna possível o alcance dos objetivos estabelecidos nas DCE (PARANÁ, 2008). Tendo isso em vista, assim como preconizado no referido documento, acreditamos que o uso de gêneros textuais como objeto de ensino possa ir ao encontro das preconizações do documento supracitado no que tange à construção de saberes de modo mais significativo para nossa realidade social.

Isso é possível porque, segundo Bakhtin (1997) e Bronckart (2009), os gêneros textuais estão intrinsecamente ligados às suas esferas sociais. Com efeito, podemos afirmar que estes acabam assumindo um caráter flexível frente às novas tecnologias e às transformações de nossa sociedade.

A riqueza e a variedade dos gêneros do discurso são infinitas, pois a variedade virtual da atividade humana é inesgotável, e cada esfera dessa atividade comporta um repertório de gêneros do discurso que vai diferenciando-se e ampliando-se à medida que a própria esfera se desenvolve e fica mais complexa (BAKHTIN, 1997, p.282).

Em consonância com os estudos de Bakhtin (1997), compreendemos que o eixo norteador das DCE é o discurso como prática social. Em determinadas instâncias comunicativas, nossos discursos se cristalizam, e é neste processo que nascem os gêneros - que não só podem ser levados para a sala de aula, como também ser o eixo para o ensino de língua inglesa e literatura em língua inglesa. Sendo assim, além de ser possível explorar amplamente os aspectos constitutivos dos textos, com a elaboração de atividades a partir dos gêneros é possível levar o aluno a ter contato com diferentes discursos de nossa sociedade, permitindo que este não só desenvolva suas ações de linguagem, como também constitua sua identidade cívica.

Para o desenvolvimento de nossa pesquisa, adotamos como corrente teóricometodológica o Interacionismo Sociodiscursivo (doravante ISD), cuja base também está apoiada em Bakhtin. Sob tal perspectiva, acreditamos que as condutas humanas são resultado de um processo histórico de socialização. Para o ISD, não basta nos limitarmos somente a aspectos neurobiológicos parar abordar tais condutas, uma vez que o ISD tem como elementar o compreender das condições sob as quais nossa espécie se organiza 
socialmente. Assim sendo, entendemos que em tal processo nós, seres humanos, nos modificamos e, por conseguinte, modificamos o curso de nossa evolução através da interação (BRONCKART, 2009).

Ao assumirmos tal concepção, automaticamente somos levados a crer que o conhecimento é inacabado, visto que evolui simultaneamente a nossas sociedades. Formar indivíduos capazes de atuar em sociedade é um dos objetivos traçados nas DCE, e tendo isso em vista compreendemos que novas ferramentas devem ser incorporadas ao processo de ensino. Isso se deve ao fato de que não faz sentido tal processo ser estático se considerarmos que a realidade para a qual os alunos estão sendo preparados não o é.

Além disso, segundo Moita Lopes (2003) e ainda debruçados nas DCE, podemos afirmar que nossas possibilidades de interação social aumentam à medida que dominamos as novas tecnologias presentes em nossa sociedade. E considerando a realidade globalizada em que vivemos e o papel da escola, acreditamos ser um dever dela tornar tais recursos acessíveis a seus alunos.

Partindo deste cenário, utilizamos como suporte de nossa SD uma webquest, que segundo Dias (2004, p. 2) é "um artefato tecnológico que promove o desenvolvimento do aprendizado crítico, a co-construção de conhecimento e a reflexão do que foi aprendido e transferência para outros domínios da vida acadêmica e pessoal dos envolvidos”. A webquest, originalmente, atua como uma metodologia. Em nosso, caso, a utilizamos como suporte para que pudéssemos desenvolver as atividades de nossa sequência didática.

Marcuschi (2003, p. 11) define suporte como "um lócus físico ou virtual com formato específico que serve de base ou ambiente de fixação do gênero materializado como texto. Numa definição sumária, pode-se dizer que suporte de um gênero é uma superfície física em formato específico que suporta, fixa e mostra um texto". O referido conceito de suporte traz consigo três premissas, a saber: suporte é um lugar físico ou virtual; suporte tem formato específico; e suporte serve para fixar e mostrar o texto.

Adotando a webquest enquanto suporte, desenvolvemos uma sequência didática (doravante SD) (DOLZ E SCHNEUWLY, 2004), que é um conjunto de atividades organizadas, cujo objetivo é viabilizar a apropriação de gêneros textuais. Tais atividades permitem que a simulação de um contexto de produção seja feita, tornando a aprendizagem de língua inglesa e literatura em língua inglesa mais significativa e próxima da realidade com que o aluno irá se deparar fora do contexto escolar. 
Consequentemente, ao tornar o gênero contemplado apreensível por meio dos módulos que a SD comporta, o desenvolvimento das capacidades de linguagem (DOLZ E SCHNEUWLY, 2004) dos alunos envolvidos neste processo também ocorre. Conforme Dolz e Schneuwly (2004), mobilizamos e articulamos as referidas capacidades no momento da produção ou leitura dos textos. Além do mais, elas estão categorizadas em três grupos, a saber: a) capacidades de ação, b) capacidades linguístico - discursivas e c) capacidades discursivas.

As capacidades de ação compreendem aspectos correlatos ao contexto de produção do texto e a qual gênero este pertence. Sendo assim, ao mobilizarmos tais capacidades, sabemos sobre quem escreveu determinado texto, para quem, quando, onde, qual o objetivo social de tal produção. As capacidades linguístico-discursivas, abordam aspectos relacionados aos recursos linguísticos utilizados para a produção textual. Em outras palavras, tais capacidades norteiam a produção do texto fonética, morfológica, sintática e semanticamente, tornando os recursos mencionados apropriados para a instância comunicativa na qual o indivíduo se inserir. E, por fim, temos as capacidades discursivas, que se referem-se à organização do texto. Sendo assim, por meio dessas capacidades conseguimos organizar as seções de um artigo acadêmico, a disposição dos elementos de uma carta de reclamação ou de quaisquer outros textos produzidos.

Para que pudéssemos iniciar a construção de nossa SD e alcançar o desenvolvimento de tais capacidades, realizamos os nossos estudos sobre William Shakespeare com base em Frye (1999). Por meio de tais estudos levantaremos questões referentes ao contexto de produção do autor renascentista e apontaremos alguns aspectos ideológicos subjacentes à sua produção. Além disso, para que possamos explorar as diferenças entre os textos elencados para a produção de nossa SD, realizamos o mesmo levantamento do contexto de produção da versão adaptada pra HQ de Yara Maura Silva e Maurício de Souza. Salientamos que tais questões relacionadas às diferenças e similaridades entre as versões contempladas neste processo serão abordadas em nossas análises.

No que se refere às atividades relacionadas ao gênero $\mathrm{HQ}$, utilizamos um modelo didático produzido por Cristovão e Durão (2008). Optamos por realizar esse trabalho com o referido gênero porque, como bem apontam as autoras, além de estar muito próximo da realidade dos alunos, a HQ é também classificada como um gênero multimodal. Sendo assim, vimos nesse gênero a oportunidade de explorar outros códigos 
linguísticos - que geralmente não são levados em consideração em atividades desenvolvidas sob uma perspectiva gramatical. Tão presente em diversas esferas sociais "o texto multimodal é aquele cujo significado se realiza por mais de um código semiótico" (KRESS \& VAN LEEUWEN, 1996 apud FERRAZ, 2008, p.1). Em outras palavras, tais textos compreendem mais de um código que, além da linguagem verbal, atribuem outros modos de significação ao discurso. Tendo o exposto em vista, ao consideramos tais códigos como elementos constitutivos de textos multimodais, acreditamos que o seu domínio e uso reflexivo também sejam importantes no momento da leitura ou produção textual.

\section{DO ALICERCE ÀS LENTES}

A fim de analisarmos aspectos constitutivos dos textos contemplados nessa pesquisa, utilizamos os estudos de Dolz e Schneuwly (2004), por meio dos quais detalharemos a forma como as capacidades de linguagem foram contempladas ao longo do desenvolvimento de nossa SD. Ademais, com base em Bronckart (2003) pretendemos apresentar a análise da sequência narrativa dos textos, uma vez que esta nos levou a compreender melhor a maneira como as versões elencadas se constituem - o que contribuiu para o desenvolvimento de nossas atividades.

\section{ANÁLISE}

Inicialmente, apresentaremos de maneira sucinta o contexto de produção dos textos contemplados nessa pesquisa. Posteriormente, discorreremos sobre o quadro com as capacidades de linguagem contempladas em nossas atividades articuladas ao plano textual global da SD (quadro 4.1). Justificamos a realização de tal análise pelo fato de que visa fornecer um mapeamento da SD, bem como descrever brevemente a maneira como nossas atividades foram desenvolvidas. Em um segundo momento, traremos o plano textual global dos textos a fim de apresentarmos a sua contribuição em nossa pesquisa. Por fim, contemplaremos questões que tocam à sequência narrativa das obras com o objetivo de verificar em que medida estão em consonância. 


\subsection{Contexto de produção das obras}

Nesse momento, teceremos brevemente algumas considerações sobre três textos, sendo dois deles pontos de partida essenciais para a construção de atividades de nossa SD (Romeo and Juliet de Shakespeare e sua versão adaptada pra HQ, por Maurício de Souza e Yara Maura Silva) e o terceiro uma adaptação que nos auxiliou no desenvolvimento de algumas das atividades que exigiram o uso de excertos (Romeo and Juliet, de Shakespeare, adaptado para conto por Charles e Mary Lamb).

O primeiro texto sobre o qual discorreremos é Romeo and Juliet de Shakespeare. Tal produção não tem uma data de criação definida, estando situada entre o final do século XVI e início do XVII. Entretanto, para Frye (1999), a peça renascentista foi uma produção mais tardia e, consequentemente, mais madura de William Shakespeare, que nasceu em 1564. Frye (1999) defende que, embora as peças de Shakespeare tenham tido vários tipos de público (desde os mais letrados até analfabetos), os ricos recursos linguísticos usados pelo poeta e dramaturgo inglês - como ambiguidades, por exemplo - eram utilizados tendo em vista espectadores mais intelectuais da época.

O segundo texto, a HQ Romeo and Juliet de Yara Maura Silva e seu irmão Maurício de Souza, foi criado em 1977 e traduzido para o inglês em 1990. Pouco após a publicação da HQ em português, surgiu a adaptação teatral, gravada em Minas Gerais, com o mesmo objetivo: trazer personagens da Turma da Mônica para o trágico universo dos jovens Capuleto e Montechio. Salientamos que, embora tenhamos trabalhado com a tradução para inglês da obra, não notamos modificações consideráveis entre os textos. Além do mais, embora HQs também sejam lidas por adultos, sabemos que grande parte do seu público é constituída por crianças e adolescentes. Por isso, consideramos importante explorar os valores subjacentes a esse texto, haja vista que, como já mencionado, segundo Cristovão e Durão (2008), o gênero HQ está muito presente na realidade dos alunos. Desse modo, apresentamos aos estudantes que em todos os textos subjazem valores, independentemente de qual seja o seu público-alvo.

Finalmente, o terceiro texto é uma adaptação para conto dos irmãos Charles e Mary Lamb, nascidos em 1775 e 1764, respectivamente. Segundo aponta Martin Amstrong, no próprio prefácio da edição de 1953 da obra, as adaptações foram publicadas em 1807, sendo nomeadas Tales from Shakespeare. Justificamos a utilização dessa versão adaptada Romeo and Juliet porque ela inegavelmente traz consigo uma 
linguagem mais acessível para a utilização de alguns de seus excertos em atividades da SD. Evidentemente, o trabalho com essa obra não excluirá, de maneira alguma, a leitura da versão original de Romeo and Juliet pelos alunos.

\subsection{Análise das capacidades de linguagem e plano textual global da sd}

Na tabela 1, trazemos os objetivos das atividades desenvolvidas na SD, por meio do seu plano textual global (BRONCKART, 2009). Essa análise objetiva basicamente apresentar um mapeamento, com todos os passos tomados no desenvolvimento das atividades. Além disso, pretendemos apresentar e comentar brevemente sobre as capacidades de linguagem (capacidade de ação - CA; capacidade discursiva - CD; capacidade linguístico-discursiva - CLD) contempladas em cada uma delas (DOLZ; SCHNEUWLY, 2004).

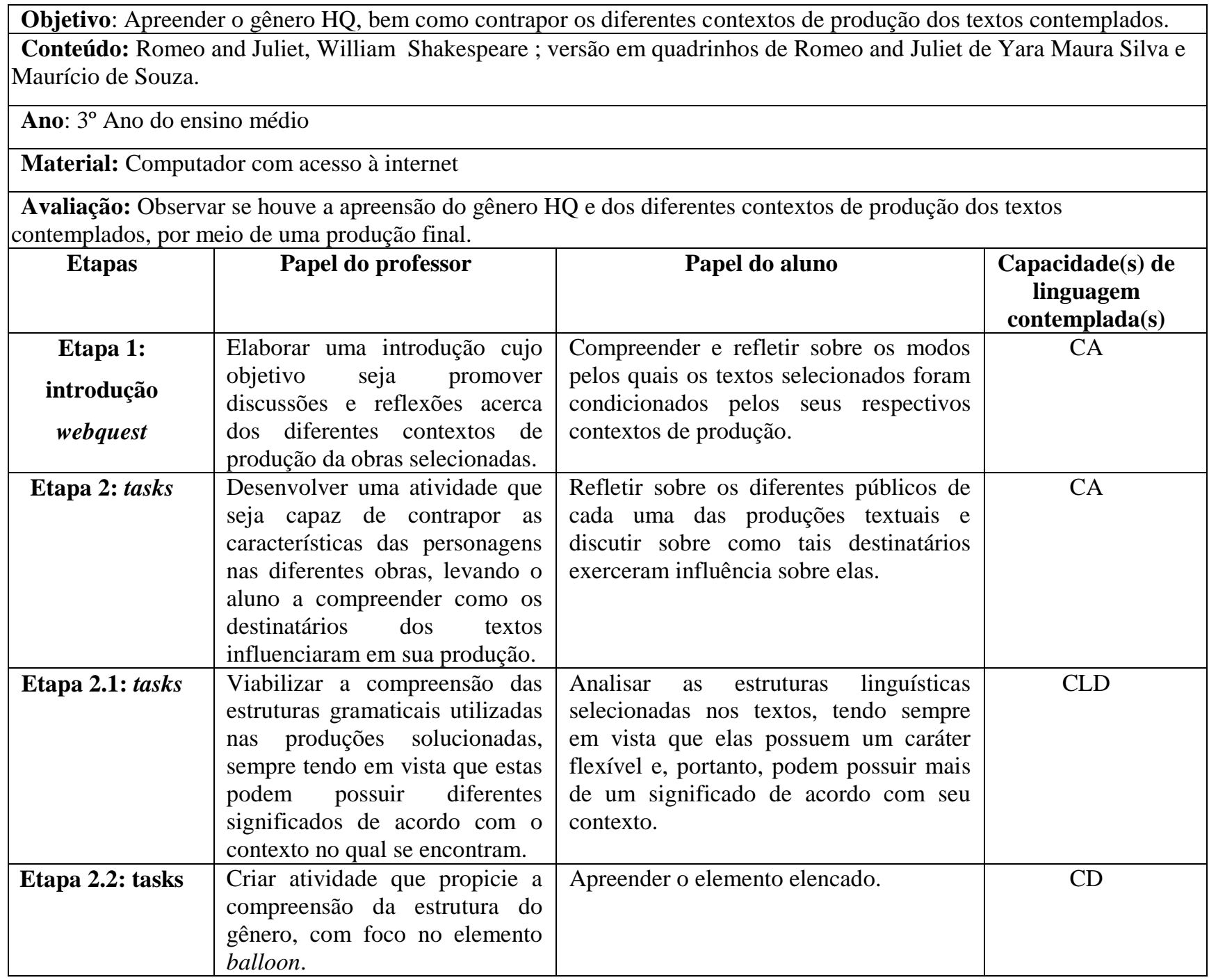




\begin{tabular}{|c|c|c|c|}
\hline Etapa 2.3: tasks & $\begin{array}{l}\text { Disponibilizar informações } \\
\text { sobre o Renascimento e suas } \\
\text { principais características e } \\
\text { motivar os alunos a buscarem } \\
\text { no texto contemporâneo } \\
\text { elementos relacionados ao } \\
\text { período histórico supracitado. } \\
\text { Além disso, evidenciar aspectos } \\
\text { visuais da HQ, explorando a } \\
\text { multimodalidade do gênero. }\end{array}$ & $\begin{array}{l}\text { Analisar a HQ de modo a compreender a } \\
\text { relação que esta possui com o contexto } \\
\text { de produção Shakespeariano. }\end{array}$ & $\mathrm{CA}$ \\
\hline Etapa 2.4: tasks & $\begin{array}{l}\text { Possibilitar a compreensão da } \\
\text { estrutura do gênero HQ e } \\
\text { explorar a intertextualidade dos } \\
\text { textos. }\end{array}$ & $\begin{array}{l}\text { Compreender a estrutura do gênero HQ e } \\
\text { a intertextualidade entre as obras } \\
\text { elencadas. }\end{array}$ & CD; CLD \\
\hline Etapa 2.5: tasks & $\begin{array}{l}\text { Levantar as diferenças entre os } \\
\text { pontos mais pertinentes de cada } \\
\text { uma das produções, levando o } \\
\text { aluno a compreender } \\
\text { exatamente em quais destes } \\
\text { referidos pontos as obras } \\
\text { possuem similaridades. }\end{array}$ & $\begin{array}{l}\text { Depreender a relação entre texto e } \\
\text { intertexto, tendo sempre em vista os } \\
\text { objetivos de tais produções. }\end{array}$ & $\mathrm{CA}$ \\
\hline
\end{tabular}

Tabela 1. Objetivos das atividades desenvolvidas na SD

Iniciamos essa análise enfatizando que as atividades sobre as quais discorreremos a seguir terão o seu início após a leitura da versão original de Romeo and Juliet, de Shakespeare, haja vista que o contato com a referida obra se faz essencial para que consigamos trabalhar o contexto de produção do texto contemporâneo (HQ) paralelamente às especificidades da versão original de Shakespeare. Desse modo, acreditamos que poderemos viabilizar a apreensão do gênero em questão, bem como contemplar saberes relacionados à disciplina literatura inglesa nesse processo.

Além do mais, como já mencionado, todas as atividades que serão descritas a seguir foram desenvolvidas em ambientes virtuais (webquest e recursos externos). Como também já dito, consideramos pertinente inserir novas tecnologias às práticas de ensino por acreditarmos que seu domínio seja essencial para o nosso atual cenário consideravelmente informatizado.

Na etapa 1, disponibilizamos um texto acerca do contexto de produção da HQ e da versão de Shakespeare. Essa esta etapa possui o objetivo de viabilizar uma melhor compreensão sobre as diferenças entre os textos contemplados, bem como levar o aluno a concluir que produções textuais são condicionadas pelos valores e especificidades de seu contexto. Ainda nesse sentido, na etapa 2, apresentamos o comportamento das personagens da HQ com o intuito de explicitar o modo como os interlocutores influenciam na produção textual. Para tanto, elaboramos uma atividade em que o aluno 
deverá indicar se a forma como as personagens agem na HQ vai ao encontro daquela geralmente vista em outras histórias da Turma da Mônica. Por sua vez, para conseguirem compreender tal questão, os alunos deverão considerar aspectos imagéticos da HQ (expressões faciais e corporais das personagens, metáforas visuais etc), o que consequentemente os levará a contemplar outros códigos linguísticos além da linguagem verbal em sua análise.

Ainda no que toca à criação das personagens, ao entrarmos em contato com os autores da HQ, Yara Maura Silva e Maurício de Souza, obtivemos a informação de que a intenção no momento da produção foi a de inserir a Turma da Mônica no universo de Shakespeare e permitir que mantivessem sua personalidade original. Sendo assim, temos também a oportunidade de enfatizar que, possivelmente, tal ocorrência se deve a questões comerciais e relacionadas ao público, além de esse diferencial em relação ao comportamento das personagens ser um dos elementos geradores de humor na trama. Para finalizarmos as considerações sobre as etapas supracitadas, salientamos que, com essas atividades, já objetivamos contemplar as capacidades de ação na SD.

Já na etapa 2.1, selecionamos algumas estruturas gramaticais que podem assumir diferentes significados, de acordo com o seu contexto. Um exemplo disso é o verbo terminado em ing que, além de apresentar outros significados, pode ainda fazer referência tanto ao marco da produção (presente), quanto ao futuro. Para alcançarmos o objetivo traçado, construímos uma tabela com estruturas gramaticais da HQ, tendo cada uma delas, no mínimo, duas definições. A partir disso, o aluno deverá considerar o contexto no qual tais estruturas gramaticais estão inseridas de modo que possa compreender qual sentido ela assume nele. Essa atividade foi elaborada com o objetivo de mostrar como a língua é flexível, sendo, portanto, essencial considerar o contexto no qual as estruturas se inserem para a compreensão clara do enunciado. Nessa etapa, por contemplarmos recursos linguísticos do gênero e por contemplarmos questões gramaticais a partir deles, demos enfoque às capacidades linguístico-discursivas.

No momento 2.2 de nossa sequência, trouxemos uma característica organizacional da HQ: os balões. Consideramos pertinente abordar tal elemento pelo fato de que existem balões que indicam fala, grito, susto, entre outras reações das personagens. Sendo assim, os balões são muito importantes para a compreensão do discurso, haja vista que atribuem novos significados a ele. A fim de levarmos os alunos a compreenderem tal especificidade do gênero HQ, utilizamos imagens de balões e uma atividade elaborada 
em um quiz para que analisem e posteriormente discutam sobre como o formato dos balões contribuem para com o sentido do texto. Por se referir a elementos organizacionais do gênero, com essa atividade, objetivamos desenvolver as capacidades discursivas.

No módulo 2.3, possuímos o objetivo de levar os alunos a explorar o universo de Shakespeare guiando-os em um processo de pesquisa virtual sobre as características principais do contexto de produção shakespeariano. Para tal, pretendemos fornecer a eles palavras-chave, que deverão auxiliá-los nessa busca. Posteriormente, os alunos deverão localizar na HQ elementos que pertençam ao contexto do autor renascentista. Será nesse momento que os alunos considerarão outros códigos semióticos da história em quadrinhos, haja vista que muita informação relacionada a essa busca está no imagético. Um exemplo disso é a arquitetura da HQ, que, em grande parte, é clássica, ou seja, está relacionada ao Renascimento, período de produção shakespeariano. Entretanto, a referida arquitetura também possui traços do Barroco de Minas Gerais. Com efeito, observamos nesse cenário uma oportunidade de apresentar aos alunos as influências do contexto de produção brasileiro no texto.

Nessa etapa, reforços ideológicos presentes nos textos serão abordados. Frye (1999) afirma que embora a rainha Elisabeth não gostasse de conflitos entre os indivíduos da sociedade elisabetana, a luta entre Romeu e a família de Julieta não é condenada, já que tem um desfecho trágico. Assim, torna-se possível compreender em que medida aqueles que detêm o poder condicionam ou até mesmo controlam o discurso. Outro possível exemplo é a expulsão de Romeu de Verona na peça, que não gera nenhum questionamento em relação à decisão do príncipe, enfatizando, assim, a supremacia do poder real. Em contrapartida, na HQ, o poder real não só é questionado, como isso é efetivamente feito por uma personagem feminina (Mônica) - ocorrência que traz uma diferente representação de poder e da mulher na contemporaneidade. Tal ocorrência, entre outras, será utilizada para exemplificar o quanto os textos se adaptam às sociedades e às suas ideologias - o que vai ao encontro dos estudos de Bakhtin, um de nossos pilares teóricos.

Além do mais, por meio desse processo, pudemos elencar aspectos relativos ao contexto de produção não só da $\mathrm{HQ}$, como também do texto literário. Assim, somado aos objetivos supracitados, vislumbramos nesse momento uma oportunidade para apresentarmos na aplicação da SD mais detalhada e cuidadosamente conteúdos relacionados à disciplina de literatura inglesa. Como articulamos o contexto de produção 
da versão em HQ ao da obra literária, visamos desenvolver as capacidades de ação dos alunos.

Finalmente, nas etapas 2.4 e 2.5, criamos uma atividade cujo objetivo é viabilizar uma melhor compreensão acerca da organização do gênero $\mathrm{HQ}$, bem como sobre a intertextualidade presente nos textos, explorando os pontos das obras que estão em consonância por meio da análise textual global. Para tanto, elencamos alguns pontos das obras (por meio de imagens e linguagem verbal) para que os alunos os organizem, relacionem e digam em que medida tais obras se comunicam. Nesse módulo, objetivamos contemplar as capacidades de ação e discursivas, uma vez que leva os alunos a compreenderem a organização do gênero, bem como especificidades dos diferentes contextos de produção.

\subsection{Infraestrutura textual}

No quadro 2, apresentaremos a infraestrutura geral dos textos contemplados. O conceito de infraestrutura adotado é o de que a infraestrutura textual é o "nível mais profundo [...], constituído pelo plano mais geral do texto, pelos tipos de discurso que comporta, pelas modalidades de articulação entre esses tipos de discurso e pelas sequências que eventualmente neles aparecem (BRONCKART, 2009, p. 120). Em tal exposição, objetivamos exibir as partes da HQ que fazem referência à organização geral da versão de Romeo and Juliet, de Shakespeare, estruturalmente falando (destaque em negrito).

\subsubsection{Atos}

\begin{tabular}{|l|l|}
\hline Versão original & Versão adaptada \\
\hline Act 1, Prologue: PROLOGUE & Part I \\
Act 1, Scene 1: Verona. A public place. & \\
Act 1, Scene 2: A street. & \\
Act 1, Scene 3: A room in Capulet's house. & \\
Act 1, Scene 4: A street. & The Balcony Scene \\
Act 1, Scene 5: A hall in Capulet's house. & \\
\hline Act 2, Prologue: PROLOGUE & \\
Act 2, Scene 1: A lane by the wall of Capulet's orchard. & \\
Act 2, SCENE II. Capulet's orchard. & \\
Act 2, Scene 3: Friar Laurence's cell. & \\
Act 2, Scene 4: A street. & \\
Act 2, Scene 5: Capulet's orchard. & \\
Act 2, Scene 6: Friar Laurence's cell. & \\
\hline
\end{tabular}


Act 3, Scene 1: A public place.

Act 3, Scene 2: Capulet's orchard.

Act 3, Scene 3: Friar Laurence's cell.

Act 3, Scene 4: A room in Capulet's house.

Act 3, Scene 5: Capulet's orchard.

Act 4, Scene 1: Friar Laurence's cell.

Act 4, Scene 2: Hall in Capulet's house.

Act 4, Scene 3: Juliet's chamber.

Act 4, Scene 4: Hall in Capulet's house.

Act 4, Scene 5: Juliet's chamber.

Act 5, Scene 1: Mantua. A street.

Act 5, Scene 2: Friar Laurence's cell.

Act 5, Scene 3: A churchyard; in it a tomb belonging to the Capulets

Quadro 2- Infraestrutura geral dos textos

Como discorrido anteriormente sobre a etapa 2.3, ao observamos o plano textual de ambos os textos, compreendemos que a HQ não contempla a mesma organização da versão original. Essa análise objetiva viabilizar a utilização de ambos os textos em sala de aula, tendo em mente quais de seus pontos estão em consonância e quais não, estruturalmente. Sendo assim, essa etapa, bem como a análise da sequência narrativa apresentada a seguir, nos permitiu elaborar atividades sobre texto e intertexto, que pretendem levar os alunos a terem contato com as obras sabendo em que medida e de que forma a versão original influenciou seu intertexto.

\subsection{Sequência narrativa}

Como já mencionado, para a produção das atividades supracitadas, analisamos a sequência narrativa de ambos os textos a fim de que tivéssemos uma visão mais clara acerca de suas características no que toca aos pontos mais pertinentes das obras. Bronckart (2003) afirma que a sequência narrativa se constitui por meio de um processo de intriga. Com efeito, "a partir de um estado equilibrado, cria-se uma tensão que desencadeia uma ou várias transformações, no fim das quais um novo estado de equilíbrio é obtido" (BRONCKART, 2003, p. 220). Dessa forma, por meio desse procedimento, podemos analisar as obras de modo a compreender em quais aspectos seus enredos se harmonizam. Além disso, a sequência narrativa é constituída de diferentes momentos, a saber: situação inicial, ação e resolução (ou ações e resoluções) e a situação final. 
Elencamos como a situação inicial a divergência entre as famílias de Romeu e Julieta, haja vista que esse é o estado inicial da narrativa. Em um segundo momento, trazemos como complicação o fato de que Romeu e Julieta se apaixonam por ser essa ocorrência aquela que desencadeia a grande tragédia, muito embora Frye (2009) também aponte a rivalidade entre as famílias como fator essencial para o nascimento da problemática. Já ação, trazemos o fato de a obra ter nascido em decorrência da complicação: após se apaixonar por Julieta, Romeu evita brigar com a família da amada e, por evitar tal confronto, um dos seus acaba morto. Esse fato o leva a matar Tybalt, que resulta em sua expulsão. Com efeito, consideramos essa expulsão como a resolução do fato de se apaixonarem. Na situação final, elencamos a tragédia que ocorre, por esse ser o desfecho da obra. Os pontos apresentados foram contemplados por nós a fim de estabelecermos comparações com os mesmos pontos da HQ. A seguir, apresentaremos os resultados dessa análise.

\section{Imagem 1: introdução à HQ}

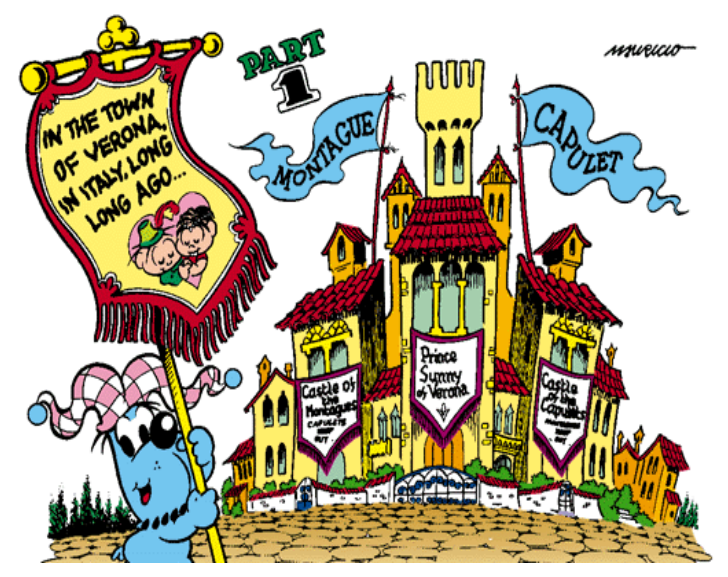

\subsubsection{Situação inicial:}

Apresentação das famílias rivais, bem como do local onde a história se passa:

\section{Imagem 2: apresentação das famílias rivais}




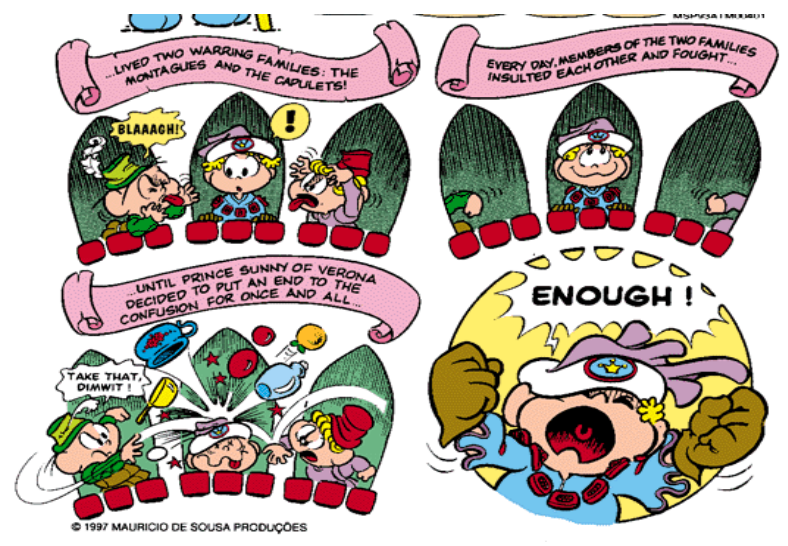

The two chief families in Verona were the rich Capulets and the Montagues. There had been an old quarrel between these families, which was grown to such a height, and so deadly was the enmity between them, that it extended to the remotest kindred, to the followers and retainers of both sides, insomuch that a servant of the house of Montague could not meet a servant of the house of Capulet, nor a Capulet encounter with a Montague by chance, but fierce words and sometimes bloodshed ensued; and frequent were the brawls from such accidental meetings, which disturbed the happy quiet of Verona's streets (1953, p.201).

\subsubsection{Complicação:}

Romeu e Julieta se apaixonam na versão original (porém, na HQ, o sentimento não aparenta ser tão recíproco assim):

\section{Imagem 3: relação entre Romeo and Juliet na HQ}

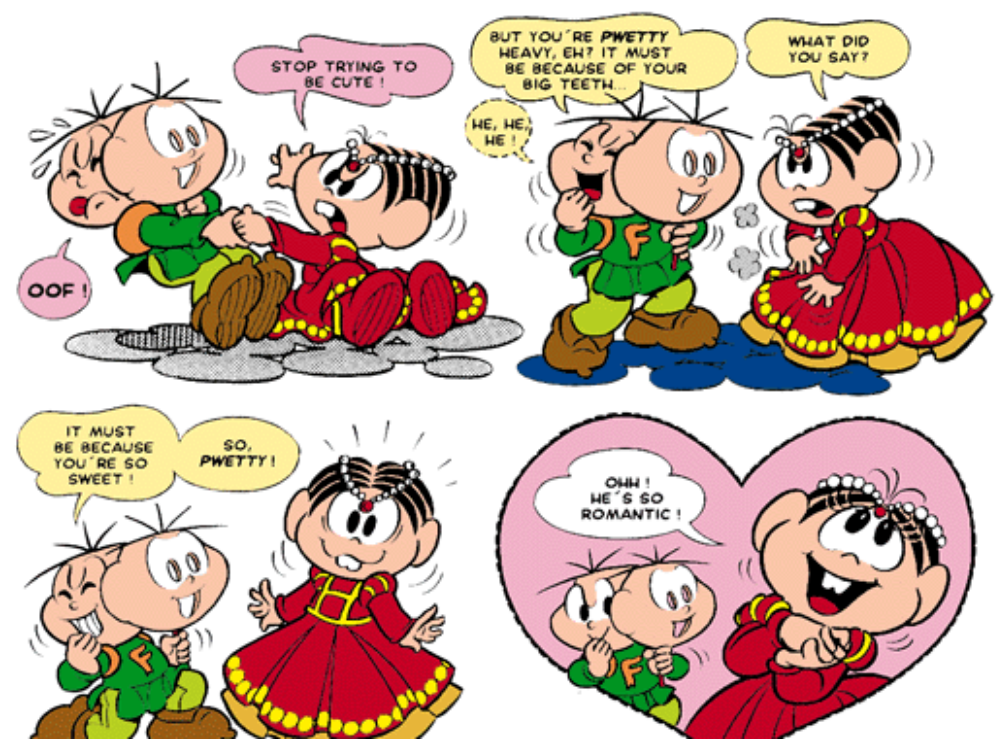


The dancing being done, Romeo watched the place where the lady stood, and under favour of his masking habit, which might seem to excuse in part the liberty, he presumed in the gentlest manner to take her by the hand, calling it a shrine, which if he profaned by touching it, he was a blushing pilgrim, and would kiss it for atonement. 'Good pilgrim,' answered the lady, "your devotion shows by far too mannerly and too courtly: saints have hands, which pilgrims may touch, but kiss not." "Have not saints lips, and pilgrims too?" said Romeo. "Ay," said the lady, "lips which they must use in prayer" (1953, p. 202).

\subsubsection{Ação e resolução:}

Ação: Confronto público entre alguns integrantes das famílias em Verona em ambas as versões:

\section{Imagem 4: confronto entre as famílias}

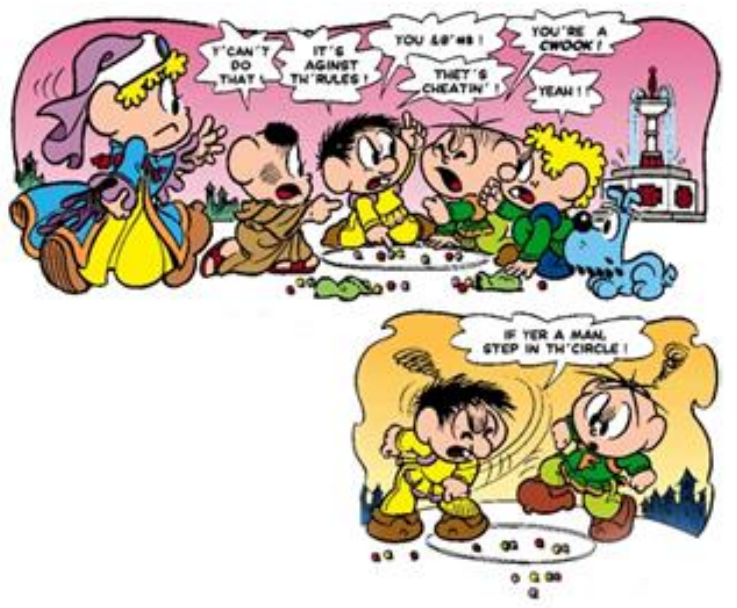

That same day, about noon, Romeo's friends, Benvolio and Mercutio, walking through the streets of Verona, were met by a party of the Capulets with the impetuous Tybalt at their head. This was the same angry Tybalt who would have fought with Romeo at old Lord Capulet's feast. He, seeing Mercutio, accused him bluntly of associating with Romeo, a Montague. Mercutio, who had as much fire and youthful blood in him as Tybalt, replied to this accusation with some sharpness [...] $(1953$, p.206).

Resolução 1 (versão original): Romeu mata Tybalt.

[...] and Tybalt and Mercutio fought, till Mercutio fell, receiving his death's wound while Romeo and Benvolio were vainly endeavouring to part the combatants. Mercutio being dead, Romeo kept his temper no longer, but returned the scornful appellation of villain which Tybalt had given him; and they fought till Tybalt was slain by Romeo (1953, p.206) 
Resolução 2: (versão em HQ): A briga não resulta em mortes.

\section{Imagem 5: briga entre as famílias na HQ}

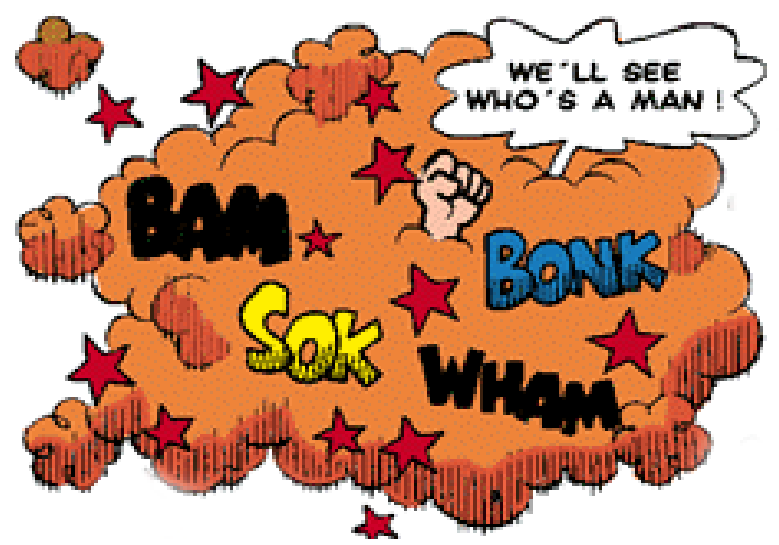

\subsection{Situação Final:}

Versão de Shakespeare: Romeu e Julieta morrem

[...] Juliet awoke out of her trance, and seeing the friar near her, she remembered the place where she was, and the occasion of her being there, and asked for Romeo [...] when Juliet saw the cup closed in her true love's hand, she guessed that poison had been the cause of his end, and she would have swallowed the dregs if any had been left, and she kissed his still warm lips to try if any poison yet did hang upon them; then hearing a nearer noise of people coming, she quickly unsheathed a dagger which she wore, and stabbing herself, died by her true Romeo's side (1953, p.213).

Versão HQ: Romeu e Julieta ficam juntos:

\section{Imagem 6: desfecho na HQ}

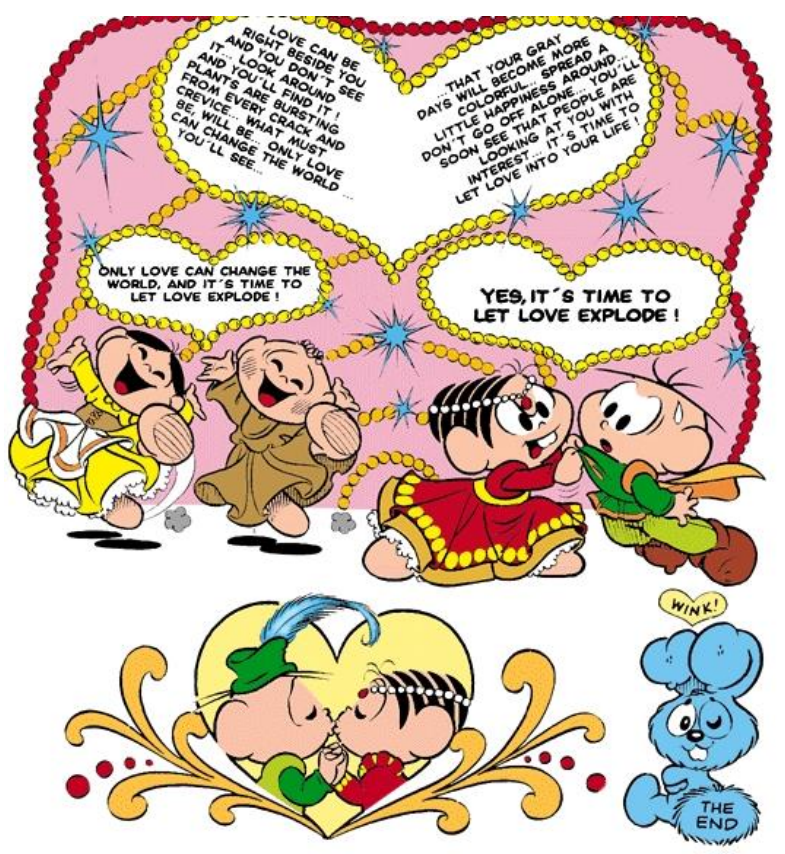


$\mathrm{Na}$ situação inicial, compreendemos que o mesmo cenário é apresentado: as famílias inimigas, o lugar em que se passa a estória etc. Sendo assim, nesse ponto, as obras estão em consonância. O mesmo ocorre com a complicação, uma vez que os dois jovens se apaixonam e isso desencadeia a problemática. Entretanto, na HQ, o sentimento de Romeo (ou Cebolinha) não aparenta ser tão recíproco. Talvez tal marca esteja presente nesse momento para indicar a personalidade de Cebolinha no universo da turma da Mônica. Já a ação e resolução da versão em HQ se apresentam bem menos violentas (sem mortes ou descrições de ira).

Isso se deve possivelmente a questões relativas aos leitores dos textos da Turma da Mônica - o que mais uma vez denota a sua grande influência na constituição da produção textual. Também indo ao encontro do exposto, o final das versões são divergentes: a HQ termina com um final feliz, ao passo que a versão original se dá de maneira trágica. Além de outros aspectos, isso também se deve a questões relacionadas ao contexto de produção, haja vista que a tragédia advém dos gregos, que exerceram forte influência sobre período renascentista de William Shakespeare, mas não da mesma forma no contexto da HQ.

Finalmente, com base nesses pontos (e também em outras ações e resoluções não apresentadas), pudemos criar módulos em nossa SD que poderão levar para a sala de aula aspectos relacionados aos diferentes contextos de produção dos textos elencados, auxiliando-nos a ter em mente em que medida as obras elencadas podem ser contrapostas de modo a alcançarmos o nosso objetivo inicial: apresentar aos alunos as obras articuladas ao seu contexto, levando-os a refletir sobre suas influências e valores.

\section{CONSIDERAÇÕES FINAIS}

Concluímos que, por meio das atividades desenvolvidas, pudemos contemplar as diferentes especificidades dos contextos de produção dos textos elencados, indo ao encontro das preconizações das DCE do Estado do Paraná, documento que defende práticas de ensino contextualizadas e que extrapolem aspectos estruturais para o ensino. Ademais, a fim de estarmos em consonância com uma perspectiva multissemiótica, exploramos e demos ênfase a características visuais da HQ, o que possivelmente levará o aluno a dominar diferentes códigos constitutivos do texto ao realizar as atividades de nossa SD. Finalmente, utilizando como suporte a webquest e desenvolvendo atividades 
virtualmente, acreditamos também contemplar na escola o contato com novas tecnologias tão presentes e essenciais em nossa sociedade atual.

\section{REFERÊNCIAS BIBLIOGRÁFICAS}

BAGNO, R., E. O. Tarefas da educação linguiística no Brasil. Revista Brasileira de Linguística Aplicada, v. 5, p. 63-82, 2005.

BAKHTIN, M. Estética da criação verbal. Tradução de Maria Ermantina Galvão G. Pereira. São Paulo: Martins Fontes, 1997.

BRONCKART, J.P. Atividades de linguagens textos e discursos. Por um interacionismo sócio-discursivo. São Paulo: EDUC, 2003/2003/2009.

CRISTOVÃO, V. L. L.; DURÃO, A. B. A. B. ; NASCIMENTO, E. L. . História em Quadrinhos em Inglês e em Espanhol: Um Gênero a Ser Desconstruido e Descrito. In: XVI Seminário do Centro de Estudos Lingüísticos e Literários do Paraná, 2003, Londrina. Anais do XVI Seminário do Centro de Estudos Lingüísticos e Literários do Paraná. Londrina: Bgf.net, 2003.

DIAS, R. Webquests no processo de aprendizagem de L2 no meio on-line. In: Vera Lúcia Menezes. (Org.). Interação e aprendizagem em ambiente virtual. 2ed. Belo Horizonte: Editora UFMG, 2010, v. , p. 359-394.

DOLZ, J.; SCHNEUWLY, B. Gêneros orais e escritos na escola. (Trad.). Rojo, R.; Cordeiro, G. S. São Paulo: Mercado de Letras, 2004.

FERRAZ, J. de A. Gêneros multimodais: novos caminhos discursivos. In: VIII Encontro Nacional de Linguagem Verbal e Não Verbal, 2008, São Paulo. Estudos do Discurso: diferentes perspectivas. São Paulo: Ideia, 2008. p. 1-14.

FRYE, N. Romeo and Juliet. In: SANDLER, Robert (Org.). Sobre Shakespeare. 2. ed. São Paulo: Editora da Universidade de São Paulo, 1999, p.29-50.

LAMB, C; LAMB, M. Romeo and Juliet. In: Tales from Shakespeare. London: Collins, 1953, p. 201-214.

MARCUSCHI, L. A. 2003. A questão do suporte dos gêneros textuais. Língua, linguística e literatura, João Pessoa, v. 1, n.1, p. 9-40.

MOITA LOPES, L. P. (2003) A nova ordem mundial, os parâmetros curriculares nacionais e o ensino de inglês no Brasil: a base intelectual para uma ação política. In: Barbara, L.; Ramos, R. C. G. (orgs.) Reflexão e ações no ensino-aprendizagem de línguas. São Paulo: Mercado de Letras, p. 29-57.

PARANÁ. Secretaria de Estado da Educação. Diretrizes Curriculares da Educação Básica: Língua Estrangeira Moderna. Curitiba: SEED, 2008.

RIOS-REGISTRO, E.S. Os livros didáticos aprovados pelo PNLD: um olhar para a coleção English for all. Semina: Ciências Sociais e Humanas, Londrina, v. 35, n. 1, p. 4156, jan./jun. 2014

SOUZA. M; SILVA, Y.M. Giant Comic Book Monica: Romeo and Juliet. 1997.

Disponível em http://www.monica.com.br/ingles/comics/rom-juli/welcome.htm. Acesso em 21 jul. 2012. 